\title{
On Tragic Fates of Major Characters in Lolita
}

\author{
Liu Xi, Wu Yi \\ Changchun University, Changchun, China
}

\begin{abstract}
Vladimir Nabokov was a noted novelist of experimentalism in the 20th century. His representative work Lolita has entered in a list of classics of modern literature and has been regarded as one of the greatest works of the 20th century. With eccentric and surreptitious style, the novel broke the traditional way of narration and the existing models of value as well as the logic and order of the rational world. It overturned the aesthetic principle of creation used in the previous novels so that the traditional value orientation has been eliminated. Lolita depicted the abnormal love between Lolita and her stepfather. This paper mainly discusses the tragic fate of the three main characters, hardships of growth, and self-indulgence which led to the twisted character and it also probes into the historic background and underlying reasons for their tragedies.
\end{abstract}

Keywords: tragic fate, desire, bewilderment, darkness

\section{Introduction}

Vladimir Nabokov is a famous contemporary Russian-American novelist. His representative work Lolita has entered in a list of classics of modern literature and has been regarded as one of the greatest works of the 20th century. With eccentric and surreptitious style, the novel breaks the traditional way of narration.

Lolita depicts a story about Humbert, the hero's perverted love for his heroine, a 12-year-old girl by the name of Lolita. Humbert was a 40-something British professor of French literature. He searched for a room to live in, and Charlotte Haze, a widowed, sexually frustrated mother, invited him to stay at her house. He declined until seeing her daughter, Dolores, affectionately called "Lolita," with whom Humbert fell in love. To be close to Lolita, Humbert accepted Charlotte's offer and became a lodger in the Haze household, and then became the stepfather of her. When Charlotte knew the truth, she run outside, got hit by a speeding car, and died. Humbert drove to Camp Climax to pick up Lolita. As they traveled across the United States, they entered a sexual relationship. In public, they acted as father and daughter. But at last, Lolita left Humbert with another man, Quilty. Years after, Humbert found Lolita and her man and killed him. In the end, Humbert was under arrest and died in the prison. Because of this seemingly sexy theme, by Humbert's tragic love, Nabokov made it a metaphor for the failure of pursuing American dream which was the bridge between them. It also revealed the failure of social morality and school education. This paper mainly discusses the tragedies of the three main characters from different perspectives so as to reveal the theme of the representative work of Nabokov: Lolita.

\section{Caged Desire of Humbert}

The first novel about pedophilia and aestheticism of Nabokov is The Enchanter, a novel written before

Liu Xi, M.A., lecturer, School of Foreign Languages, Changchun University.

Wu Yi, M.A., associate professor, School of Foreign Languages, Changchun University. 
Lolita by 16 years. The main character in the Enchanter, Arthur, like Humbert, was depicted as a "central European." He was a middle-aged pedophile, too. He married a dying French woman to get close to her 12-year-old daughter. Soon after, the French woman died, Arthur took the girl to a remote small hotel in Switzerland. Then, someday, Arthur came to fondle with the girl until she woke up. The girl did not understand what was happening and she began to weep and scream. With panics, Arthur rushed out of the hotel and was hit by a large truck on the road. Due to the oversensitive theme and plot of the novel, Nabokov gave up its publication. Consequently, he reinvented the story through Lolita. Though The Enchanter failed, it could be viewed as a good prologue to Lolita because they almost followed the same style from the perspective of the theme and the plot. Some basic ideas were retained in Lolita, at first, both Arthur and Humbert were pedophiles, they used many literary techniques to prettify their desire. For another, both girls were unique to them. They were so unique to them that both of the two old men converted the girls into something they could take advantage of in order to justify their actions. Humbert called Lolita "my Lolita" or "my prey." In his eyes, Lolita was not the ordinary girl what she was really to be. He had changed Lolita into what she was not, Humbert's creation, the beautiful impression. Similarly, Arthur cheated to the 12-year-old girl's uniqueness. In both cases, the two old men were called pedophile by the traditional ideas. Furthermore, both of the pedophiles asserted that they were real interested in artistry. Take Humbert for example, he described the first tryst with Lolita and said that he had no interest in "so-called 'sex' at all" (Nabokov, 1990, p. 134), he was just to "fix once for all the perilous of nymphet" (Nabokov, 1990, p. 134). Arthur followed the same example as Humbert because he considered his desire "refined" and "special" (Nabokov, 1991, p. 5).

Even today,

Long after incest and scatology and sexual violence have become merely naughty, pedophilia remains a signal either of absolute evil or of mental derangement in the sense that artworks, whether conventional or avant-grade, are generally straightforward in representing it as such. (Andrews, 1999, p. 66)

Nabokov did not comprehend the pedophilia in the traditional way of thinking. He put many masks in Lolita, just like a riddle, he tried his best in artistic techniques to satisfy his aesthetic conscience. On the other hand, he had also satisfied his social conscience to the pedophilia. Nabokov went through so many difficulties in creating Lolita so that it was a great honor for him to explain his choice of his subject matter. In this sense, when Nabokov talked about Lolita, he merely said, "That was a work of art, and it had a high moral content" (Field, 1986, p. 306).

However, The Enchanter, the precursor, or Lolita, the successor, the two novels are all about the desire of humans. What Humbert experienced was the best demonstration of a caged soul who failed to reveal his real desires openly and always hid all his sexual thought carefully.

\section{Bewildered Life of Lolita}

"Lolita is a grenade tossed into the landscape of the 1950s' culture, exploding the myth of sexless and saintly children created by Rousseau and Wordsworth at the birth of Romanticism" (Lamour, 2002, p. 79). Along with the popularity of Lolita, "the Lolita Complex (an unhealthy desire for underage girls), and the Lolita Syndrome (the secret longing of middle-aged males for a young gir1), are known today both clinically and in the vernacular" (Lamour, 2002, p. 153). 
Lolita was a self-indulged, naughty child. The death of her father, the bully of the boys, and the selfishness of the mother made her a stubborn and rude girl, and she became a "complete pest" in her mother's eye. What the mother did showed how to condemn the hurt from a selfish and irresponsible mother. As a child from a single-parent family, Lolita had some deficiency in her character caused by such a family, that was, the shortage of love and influence from a father. Therefore, she knew little about adult males, and she was easily influenced by the big environment around her, the mass culture.

Lolita's brand of Nabokov - which leaves her more vulnerable, in some ways, than a child who lacks her pretense of knowing sophistication-poignantly attests to the intrusive power of the media. Forming her notions of reality from images projected on the silver screen, she has no idea that adult experience transcends the Hollywood gestures and ritual movie kiss she has learned to imitate. (Pifer, 2000, p.77)

The pure smile which was covered by Lolita's heavily make-up and the profound eye behind the glasses showed that what she longed for was just fatherly love. She had great hope for Humbert. When she sat on his desk and put up her legs on his body, she was innocent. Being together with Humbert, she was pampered and she loved this feeling. While her innocence was imposed by Humbert, she was a victim, too, not only because she was a child, but also she's hunt by the cheat and selfish man in the adult world. Her precocious thinking and behaved towards Humbert with too great familiarity were called inducement. In Lolita' life, she had never understood the love of Humbert, she simply thought about her needs and ignored the real aim of Humbert. Thus, they only brushed past each other, but by chance, they found the same point on desire. The two persons dropped into the desire abyss with harbor sinister designs.

After picking up Lolita from the camp, when Lolita kissed him, Humbert knew clearly that "it was but an innocent game on her part, a bit of backfisch foolery in imitation of some simulacrum of fake romance" (Nabokov, 1990, p. 120). He deprived her of a rightful childhood, which was the most vicious deed done to a child. He made use of her innocent game to fulfill his debauched illusion. When she saw the other father caressed his daughter, her smile became lackluster suddenly. All the children had families, but she had none. Thus, in this sense, Lolita's adolescence was mainly accompanied with a period of molested time. She was a typical example among those who have the same experiences with her and the sacrifice of Humbert, of an adult's illusion. Finally, Lolita left him. She would rather choose a mediocre carpenter rather than wandering with Humbert. She chooses the quiet life. Is that the regression of moral? But unfortunately, she died at last.

Actually, this kind of "Lolita phenomenon" had common meaning on adolescents in the 21 st century. Influenced greatly by the mass media, which was full of fake romance, many adolescents had no judgment and could not discern the reality and the illusion about love. As for the short life of the poor girl Lolita, it was a total tragedy which merely reflected her bewilderment towards adults' world.

\section{Dark Side of Quilty}

Incidental clues to Quilty's identity appeared throughout the novel. The first time Quilty appeared in the novel was in the same hotel, the Enchanted Hunters, where Humbert had first sex with Lolita in their first trip after Charlott's death. Nabokov concealed Quilty's importance to the story until nearly the end of it. Quilty was a man who was abnormal, highly literate, and completely corrupt. Physically, Quilty appeared infrequently in the novel, but his presence asserted itself through a relentless series of hidden clues. During their stay in Bearsley, where Lolita began her school life as a high school student, Quilty appeared again. But Humbert failed to recognize Quilty because of his dread. Though Humbert "detests the theatre as being a primitive and 
putrid form" (Nabokov, 1990, p. 200), he had to allow Lolita to take part in the stage play for fear that Lolita would not offer him his pleasure. Thus, it was Humbert who provided the chance which Lolita met with Quilty, the man who she loved when she was only 10 years old, and the man who helped her to escape from Humbert. During their second trip, when Humbert was aware of the existence of the rival, sometimes he could catch the sight of him "a broad-backed man, baldish, in an oatmeal coat and dark-brown trousers," but he still fails to speculate the identity of Quilty, and calls the man "Gustave Trapp, a cousin of his father's in Switzerland" (Nabokov, 1990, p. 231). When Lolita took part in the Quilty's stage play in Wace, Humbert remembered the playwright's name-Quilty.

Humbert devoted his remaining years to pursuing his rival and solving the riddle of Quilty's identity. The man had stripped him of all that he loved. The state of isolation, despair, and hatred had reduced him a murderer long since. Especially, with the revelation of Quilty's identity, his feelings of fear and desperation were well demonstrated in the story.

When Humbert gave himself "at least thirty-five years for rape, and dismissed the rest of the charges" (Nabokov, 1990, p. 327), it can be confirmed that he dismissed chiefly the charge of murdering Quilty with the insistence on the distinction between the technical charges he faced and his desire for Lolita.

In the contest of Humbert and Quilty, the arrogant Humbert was involved in the feelings of desperation for losing Lolita, and of disgrace from Quilty's torturing him. Humbert gave himself over to the pleasure which offered by Lolita, which led to lose the game and Lolita to Quilty. He should be part of the designing of the novel, which for the reason that his abduction of Lolita makes himself the mortal enemy of Humbert and that in killing him, Humbert turned into a murderer.

The mysterious role and place of Clare Quilty was cleared up when eventually came the encounter between Humbert and Quilty. The scene of the murder was the most curious and dramatic episode in Lolita. In the florid and protracted murder, they were rolling about the floor of Pavor Manor tussling for possession of chum the gun and appeared indistinguishable from one another. Humbert literally confused Quilty's identity with his own. As their separate identities began to merge in Humbert's mind, the ludicrous tussle became a muddle of personal pronouns, “... and I felt suffocated as he rolled over me. I rolled over him. We rolled over me. They rolled over him. We rolled over us" (Nabokov, 1990, p. 301). The seemingly misuse of the pronoun indicated to us that Humbert was identified with Clare Quilty and Clare Quilty was in fact his double. Quilty, the pervert and pedophile, served as a nasty, even more brutish reflection of Humbert's "monstrous" lust in himself.

When the major characters' fate change thoroughly in the end, everything was irretrievable, Lolita became a mother while Quilty died. Humbert ultimately gave himself up after he went through years of going around and contending for his fate. For the past three years in the prison, he always thought of the desperation and helplessness in the eyes of Lolita when she could not enjoy a childhood as she once wished. He hated himself of depriving her of her rightful childhood. When he heard the melody of children at play in the street, then he knows that "the hopelessly poignant thing was not Lolita's absence from my side, but the absence of her voice from that concord" (Nabokov, 1990, p. 326). Actually, though Quilty once brought hopes and brightness to Lolita, nobody could deny the darkness in his thoughts, which carried the real significance of the theme in the novel.

\section{Conclusion}

With a dangerously risky theme, Nabokov told us a story that a middle-aged widower fell in love with his stepdaughter, and made it a framework to make up a world which was far from the reality and kicked over the 
traces of moral. The core tasks of this novel were not a simple heartbroken story, but a story to stress the nature of human being full of lust. As an aesthete, Nabokov's aestheticism is a strange, idiosyncratic form, one stressing careful perception and intellection, one grounding aesthetic bliss in curiosity, tenderness, and kindness. Therefore, Lolita's lasting charm lies in its tracing back to the Greek original meaning of aestheticism, aesthesis, an activity removing the prejudice against aestheticism by making literary use of that prejudice, daring his readers to perfect the power to perceive. The three main characters had the similar tragic fates which reflected the social reality at their contemporaneous backgrounds.

\section{References}

Alfred Appel, Jr. (1970). The annotated LOLITA, by Vladimir Nabokov. New York, N.Y.: McGraw-Hill Press.

Andrews, D. (1999). Aesthetism, Nabokov and Lolita. Lampeter: Edwin Mellen Press.

Bloom, H. (1993). Major literary characters —Lolita. New York, N.Y.: Chaelsea House Publishers.

Boyd, B. (1991). Vladimir Nabokov: The American years. Princeton, N.J.: Princeton Publishing Press.

Clancy, L. (1984). The novels of Vladimir Nabokov. London, U.K.: The Macmillan Press Ltd..

Field, A. (1986). The life and art of Vladimir Nabokov. New York, N.Y.: Crown Publishers, Inc..

Lamour, D. H. J. (2002). Discourse and ideology in Nabokov's prose. London, U.K.: Routledge Press.

Nabokov, V. (1990). Lolita. Beijing: Foreign Language Teaching and Research Press.

Pifer, E. (2000). Demon or doll-images of the child in contemporary writing and culture. London, U.K.: University Press of Virginia.

Yu, W. X. (2002). Cultural study: An introduction. Beijing: People Press. 